Section Editor

Mitchell S.V. Elkind, MD, MS

\title{
Teaching NeuroImages: \\ Extracranial internal carotid artery aneurysm causing embolic stroke
}

Kristian Barlinn, MD Jessica Kepplinger, MD Volker Puetz, MD Ulf Bodechtel, MD

Correspondence to

Dr. Barlinn:

Kristian.Barlinn@uniklinikumdresden.de

Download teaching slides: Neurology.org

\section{Figure MRI and carotid ultrasound findings}

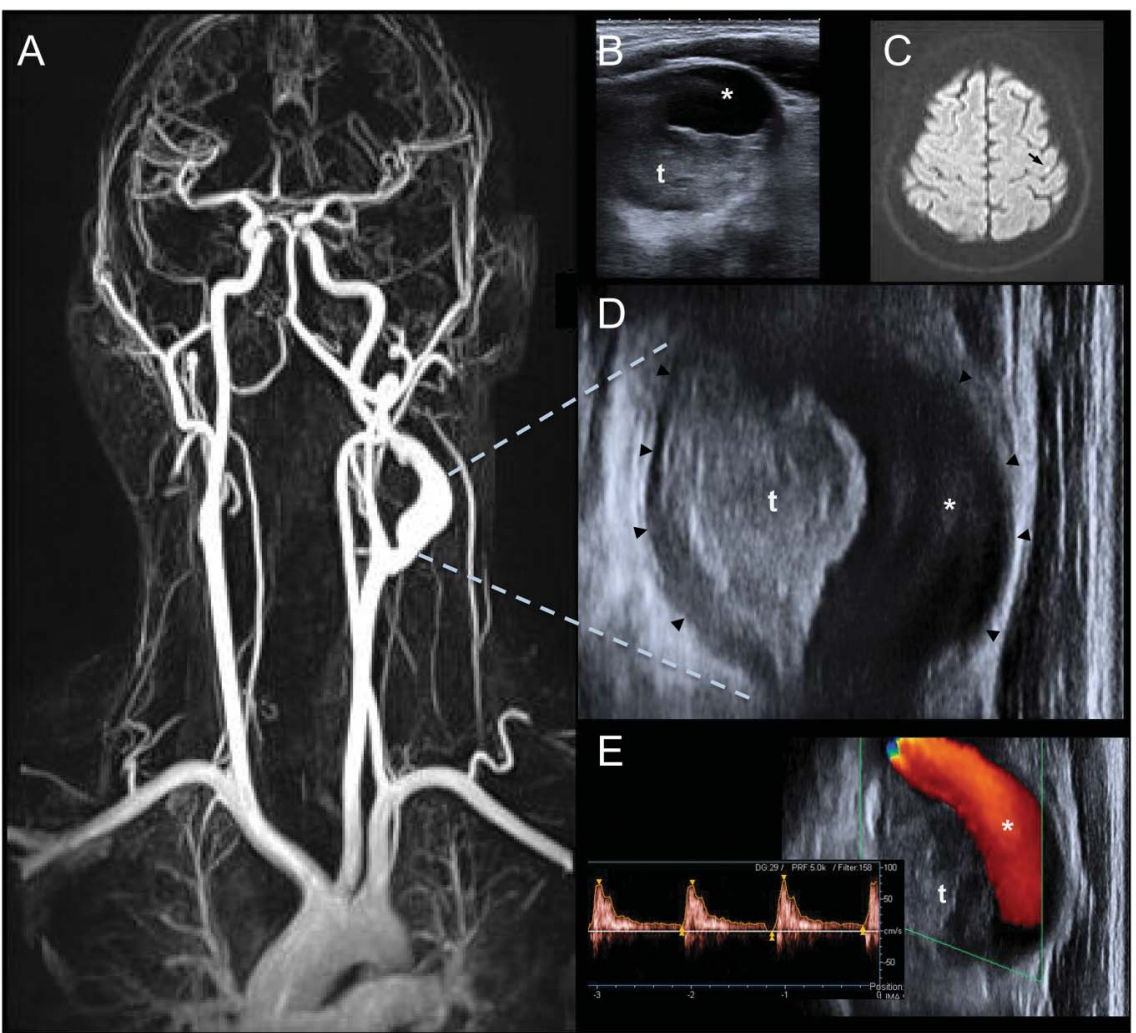

(A) Magnetic resonance angiography: fusiform aneurysm of left proximal internal carotid artery (ICA). Carotid ultrasound, (B) transverse and (D) longitudinal views: distinct widening of left proximal ICA (vessel wall, arrowheads) and intraluminal thrombus (t). (C) MRI-diffusion-weighted imaging: acute embolic infarction in the left precentral gyrus (arrow). (E) Normal Doppler flow analysis in the remaining lumen (*).

A 42-year-old man with no history of trauma experienced acute numbness in his right arm and leg. A pulsating left cervical tumor was noted on clinical examination. Carotid ultrasound demonstrated significant widening of the left proximal internal carotid artery (ICA) and a large nonocclusive hypoechoic structure compatible with an aneurysm and intraluminal thrombus (figure, B, D, and E). MRI confirmed a fusiform extracranial ICA aneurysm and showed a left-sided small embolic stroke (figure, A and C). The patient underwent anticoagulation with low-molecular- weight heparin and eventually surgical treatment (i.e., resection and saphenous vein graft interposition). Histopathology revealed severe atherosclerosis. Extracranial ICA aneurysms are rare and can cause embolic stroke. ${ }^{1}$ The underlying etiology is diverse, with atherosclerosis being the most common entity. ${ }^{2}$

\section{AUTHOR CONTRIBUTIONS}

Dr. Barlinn obtained the images, prepared the figure, and wrote the case summary. Dr. Kepplinger assisted in preparation of the figure and contributed to drafting and revising the manuscript. Dr. Puetz and Dr. Bodechtel contributed to revising the manuscript.

From the Department of Neurology, University of Technology Dresden, Germany

Go to Neurology.org for full disclosures. Funding information and disclosures deemed relevant by the authors, if any, are provided at the end of the article. 
STUDY FUNDING

No targeted funding reported.

\section{DISCLOSURE}

The authors report no disclosures relevant to the manuscript. Go to Neurology.org for full disclosures.
REFERENCES

1. El-Sabrout R, Cooley DA. Extracranial carotid artery aneurysms: Texas Heart Institute experience. J Vasc Surg 2000;31:207-212.

2. Rosset E, Albertini JN, Magnan PE, Ede B, Thomassin JM, Branchereau A. Surgical treatment of extracranial internal carotid artery aneurysms. J Vasc Surg 2000;31:713-723. 


\section{Neurology}

\section{Teaching NeuroImages: Extracranial internal carotid artery aneurysm causing embolic stroke}

Kristian Barlinn, Jessica Kepplinger, Volker Puetz, et al.

Neurology 2014;83;e48-e49

DOI 10.1212/WNL.0000000000000604

\section{This information is current as of July 14, 2014}

\section{Updated Information \& Services \\ Supplementary Material \\ References \\ Subspecialty Collections}

Permissions \& Licensing

Reprints including high resolution figures, can be found at: http://n.neurology.org/content/83/3/e48.full

Supplementary material can be found at: http://n.neurology.org/content/supp1/2014/07/13/83.3.e48.DC1

This article cites 2 articles, 0 of which you can access for free at: http://n.neurology.org/content/83/3/e48.full\#ref-list-1

This article, along with others on similar topics, appears in the following collection(s):

\section{Embolism}

http://n.neurology.org/cgi/collection/embolism

MRI

http://n.neurology.org/cgi/collection/mri

Stroke in young adults

http://n.neurology.org/cgi/collection/stroke_in_young_adults Ultrasound

http://n.neurology.org/cgi/collection/ultrasound

Information about reproducing this article in parts (figures,tables) or in its entirety can be found online at:

http://www.neurology.org/about/about_the_journal\#permissions

Information about ordering reprints can be found online: http://n.neurology.org/subscribers/advertise

Neurology ${ }^{\circledR}$ is the official journal of the American Academy of Neurology. Published continuously since 1951, it is now a weekly with 48 issues per year. Copyright () 2014 American Academy of Neurology. All rights reserved. Print ISSN: 0028-3878. Online ISSN: 1526-632X.

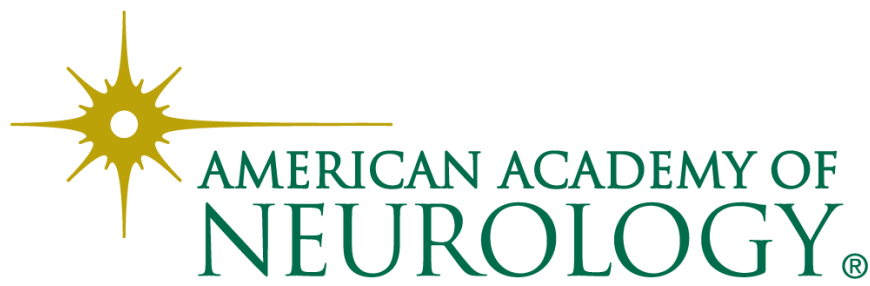

